\title{
QUALITY OF LIFE IN PATIENTS WITH ROTATOR CUFF ARTHROPATHY
}

\section{QUALIDADE DE VIDA NOS PACIENTES COM ARTROPATIA DO MANGUITO ROTADOR}

\author{
Arnaldo amado Ferreira Neto ${ }^{1}$, Eduardo Angel Malavolta ${ }^{1}$, Jorge Henrique Assunção ${ }^{* 1}$, Mauro Emilio Conforto Gracitelli ${ }^{1}$, \\ Guilherme Pereira Ocampos ${ }^{1}$, Evelinda Marramon Trindade ${ }^{2}$
}

1. Instituto de Ortopedia e Traumatologia, Hospital das Clínicas, Faculdade de Medicina da Universidade de São Paulo, São Paulo, SP, Brazil.

2. São Paulo State Health Technology Assessment Network, São Paul State Department of Health, São Paulo, SP, Brazil.

\section{ABSTRACT}

Objective: To compare quality of life (according to the SF-12) in patients with rotator cuff arthropathy with controls paired by sex and age. Secondary objectives are to compare the groups according to the ASES and VAS scales. Methods: This cross-sectional study with controls paired by sex and age compared patients with rotator cuff arthropathy with surgical indication for reverse shoulder arthroplasty. The groups were compared according to the SF-12, ASES, and VAS scales. Results: The groups consisted of 38 individuals, 28 women. The SF-12 demonstrated a significant difference in the physical component, with the cases scoring $31.61 \pm 6.15$ and the controls $49.39 \pm 6.37(p<0.001)$. For the mental component, the difference was not significant, with the cases scoring $44.82 \pm$ 13.18 and the controls $48.96 \pm 8.65(p=0.109)$. The cases scored $7.34 \pm 2.11$ on the VAS and $31.26 \pm 15.12$ on the ASES, while the controls scored $0.55 \pm 1.31$ and $97.53 \pm 6.22$, respectively $(p<0.001)$. Conclusion: Patients with rotator cuff arthropathy had poorer results for the physical component of the SF-12 than the controls. They also had poorer functional results according to the ASES scale, and more pain according to the VAS. Level of Evidence III, Case Control Study.

Keywords: Arthroplasty, replacement. Joint diseases. Osteoarthritis. Rotator cuff. Quality of life.

\section{RESUMO}

Objetivo: Comparar a qualidade de vida, de acordo com o SF-12, entre pacientes com artropatia do manguito rotador e controles pareados por sexo e idade. É objetivo secundário a comparação dos grupos de acordo com as escalas ASES e EVA. Métodos: Estudo transversal com controles pareados por sexo e idade, que comparou pacientes com artropatia do manguito rotador e indicação de artroplastia reversa do ombro com indivíduos sadios. Os grupos foram comparados quanto às escalas SF-12, ASES e EVA. Resultados: Os grupos foram formados por 38 indivíduos, sendo 28 do sexo feminino. O SF-12 apresentou diferença significativa no componente físico, tendo os casos registrado $31,61 \pm 6,15$ e os controles $49,39 \pm 6,37$ $(p<0,001)$. Para o componente mental, a diferença não foi significativa, tendo os casos apresentado 44,82 $\pm 13,18$ e os controles $48,96 \pm 8,65(p=0.109)$. Os casos apresentaram EVA de 7,34 $\pm 2,11$ e ASES de 31,26 $\pm 15,12$, enquanto os controles apresentaram 0,55 $\pm 1,31$ e $97,53 \pm 6,22$, respectivamente $(p<0,001)$. Conclusão: Os pacientes com artropatia do manguito rotador apresentam piores resultados no componente físico do SF-12 quando comparados aos controles. Têm, ainda, piores resultados funcionais pela escala da ASES e mais dor pela EVA. Nível de Evidência III, Estudo de Caso-Controle.

Descritores: Artroplastia de substituição. Artropatias. Osteoartrose. Manguito rotador. Qualidade de vida.

Citation: Ferreira Neto AA, Malavolta EA, Assunção JH, Gracitelli ME, Ocampos GP, Trindade EM. Quality of life in patients with rotator cuff arthropathy. Acta Ortop Bras. [online]. 2017;25(6):275-8. Available from URL: http://www.scielo.br/aob.

\section{INTRODUCTION}

Arthropathy of the rotator cuff is arthritis of the glenohumeral joint associated with massive rupture of the rotator cuff. ${ }^{1}$ This injury affects $2.5 \%$ of the population over age $70^{2}$ and can lead to pain and significant functional limitations. ${ }^{1}$

Scales that assess quality of life (QOL) are often used in studies of osteoarthritis. The significant impact this condition has on patient QOL has already been described for osteoarthritis of the knee, ${ }^{3-6}$ the hip, ${ }^{3,5,6}$ and the hand. ${ }^{6,7}$
Few studies evaluate the effect of reverse arthroplasty of the shoulder on patient QOL, whether this procedure treats degenerative injury ${ }^{8}$ or fractures. ${ }^{9}$ However, no study as of this time has compared QOL in patients with arthropathy of the rotator cuff with that of a control group.

The primary objective of this study is to compare QOL as measured by the Short Form 12 Health Survey $(\mathrm{SF}-12)^{10}$ between patients with rotator cuff arthropathy with indication of reverse arthroplasty and controls matched for sex and age. Secondary objectives are to

All authors declare no potential conflict of interest related to this article.

Work conducted at the Grupo de Ombro e Cotovelo do Instituto de Ortopedia e Traumatologia, Hospital das Clinicas, Faculdade de Medicina, Universidade de São Paulo, São Paulo, SP, Brazil.

Correspondence: Rua Dr. Ovídio Pires de Campos, 333, 3ªndar, São Paulo, SP, Brazil. 05403-010. drjorgeassuncao@gmail.com

Article received in 12/26/2016, approved in 05/26/2017. 
compare the groups according to function and pain, using the scales from the American Shoulder and Elbow Surgeons Standardized Shoulder Assessment Form (ACES) ${ }^{11}$ and the visual analog scale for pain (VAS).

\section{MATERIALS AND METHODS}

We conducted a cross-sectional study with matched controls at a 1:1 ratio. At our institution's outpatient clinic, we assessed patients with a diagnosis of arthropathy of the rotator cuff and indication for reverse arthroplasty of the shoulder, with respect to their QOL. The control group was composed of people accompanying patients to the same outpatient clinic, who were matched by sex and age. An age difference of \pm 2 years was tolerated.

The patients were assessed between July 21, 2015 and April 13, 2016. The study was approved by the institutional review board under process number 1103 and did not receive any type of funding.

\section{The criteria for indication of reverse arthroplasty were:}

- Diagnosis of arthropathy of the rotator cuff

- Active elevation of less than $90^{\circ}$

- Unsuccessful non-surgical treatment performed for at least 6 months.

\section{After the informed consent form was signed, information on the following variables was collected in an interview:}

- The quality of life scale from the Short Form 12 Health Survey (SF-12), ${ }^{10}$ considering the primary outcome;

- Functional scale from the American Shoulder and Elbow Surgeons Standardized Shoulder Assessment Form (ASES) ${ }^{11}$ and visual analog pain scale (VAS), secondary outcomes;

- Demographic data: sex, age, clinical comorbidities (cardiovascular, pulmonary, neurological, rheumatic, urological, endocrine, psychiatric, immunological, and neoplastic disorders), orthopedic comorbidities (spine, shoulder and elbow, wrist and hand, hip, knee, foot and ankle), body mass index (BMI), and number of medications taken daily;

- Presence or absence of pain in the shoulder, and duration of symptoms.

\section{Calculation of the sample}

The minimal clinically important difference (MCID) on the SF-12 has not yet been established for rotator cuff arthropathy. In a study on total knee arthroplasty, the MCID was determined to be 4.8 points for the physical component of the SF-12, with a standard deviation of $10.4 .{ }^{12}$ In a conservative scenario, considering a MCID of 10 points and a standard deviation of 15 , we would need 36 individuals in each group.

\section{Statistical analysis}

We assessed the normality of the continuous variables using the Kolmogorov-Smirnov test, and homogeneity using the Levene test. The continuous quantitative variables were expressed as means and standard deviation, while the categorical variables were expressed as absolute values and percentages.

The comparison between the cases and controls with respect to the different variables was performed using the chi-squared or Fisher's exact test for the categorical variables. For the continuous variables, this comparison was assessed using the non-paired Student's t test if the data was parametrically distributed, or the Wilcoxon test for non-nonparametric distribution.

We used SPSS version 20.0 software (SPSS Inc, Chicago, Illinois, USA) for the data analysis, and a significance level of $5 \%$.

\section{RESULTS}

The institution's database included 45 patients recommended for reverse arthroplasty of the shoulder. Five of these could not be located, one had died, and one did not agree to take part in the study. Consequently, 38 patients were interviewed to comprise the case group cases, and an equal number were selected as controls. The two groups had 28 women.

The cases had involvement of the right side in $68.4 \%$ (26/38), the left side in $23.7 \%(9 / 38)$, and bilateral involvement in $7.9 \%(3 / 38)$. The mean time they experienced symptoms was 128.97 months. The groups did not differ significantly in age, BMI, or previous surgeries in sites other than the shoulder $(p=0.878, p=0.159$ and $p=0.489$, respectively). The comorbidities, excluding rheumatic diseases $(p=0.028)$, also showed no differences between the groups. The patients recommended for reverse arthroplasty used a significantly larger number of medications $(p=0.021)$. With respect to orthopedic diseases, the cases had significantly more shoulder symptoms $(p<0.001)$ and no significant difference in other locations. The general characteristics of the sample can be seen in Table 1.

Table 1. General characteristics of the sample.

\begin{tabular}{|c|c|c|c|}
\hline & Cases & Controls & $p$ \\
\hline \multicolumn{4}{|l|}{ Sex } \\
\hline Men & 10 & 10 & $>0.999$ \\
\hline Women & 28 & 28 & \\
\hline Age (years) & $67.34 \pm 8.02$ & $67.05 \pm 8.33$ & 0.878 \\
\hline Body mass index & $28.10 \pm 5.65$ & $26.54 \pm 3.66$ & 0.159 \\
\hline \multicolumn{4}{|l|}{ Comorbidities } \\
\hline Hypertension & 28 & 27 & 0.798 \\
\hline Cardiovascular diseases & 1 & 3 & 0.615 \\
\hline Rheumatic diseases & 8 & 1 & 0.028 \\
\hline Lung diseases & 1 & 0 & $>0.999$ \\
\hline Neurological diseases & 3 & 1 & 0,615 \\
\hline Urological diseases & 0 & 0 & $>0.999$ \\
\hline Diabetes mellitus & 5 & 7 & 0.754 \\
\hline Hypercholesterolemia & 6 & 4 & 0.736 \\
\hline Hypothyroidism & 6 & 2 & 0.262 \\
\hline Psychiatric diseases & 6 & 5 & $>0.999$ \\
\hline Immunologic diseases & 0 & 0 & $>0.999$ \\
\hline Neoplastic diseases & 0 & 1 & $>0.999$ \\
\hline Number of medications per day/patient & $4.47 \pm 3.28$ & $2.87 \pm 2.63$ & 0.021 \\
\hline $\begin{array}{l}\text { Previous orthopedic surgeries } \\
\text { (other than shoulder) }\end{array}$ & 23 & 19 & 0.489 \\
\hline $\begin{array}{c}\text { Number of patients with previous } \\
\text { shoulder surgeries }\end{array}$ & 13 & 1 & $<0.001$ \\
\hline \multicolumn{4}{|l|}{ Orthopedic diseases } \\
\hline Spine & 4 & 6 & 0.736 \\
\hline Shoulder & 38 & 5 & $<0.001$ \\
\hline Hand and wrist & 3 & 1 & 0.615 \\
\hline Hip & 4 & 0 & 0,115 \\
\hline Knee & 11 & 4 & 0.082 \\
\hline Foot and ankle & 3 & 1 & 0.615 \\
\hline
\end{tabular}


The SF-12 showed a significant difference in the physical component, with the cases scoring $31.61 \pm 6.15$ and the controls $49.39 \pm$ $6.37(p<0.001)$. For the mental component, the difference was not significant, with the cases scoring $44.82 \pm 13.18$ and the controls $48.96 \pm 8.65(p<0.109)$. The cases presented a VAS score of 7.34 \pm 2.11 , and ASES score of $31.26 \pm 15.12$, while the control scores were $0.55 \pm 1.31$ and $97.53 \pm 6.22$, respectively $(p<0.001)$. The data can be seen in Table 2 .

\begin{tabular}{|c|c|c|c|}
\hline & Cases & Controls & $p$ \\
\hline VAS & $7.34 \pm 2.11$ & $0.55 \pm 1.31$ & $<0.001$ \\
\hline ASES & $31.26 \pm 15.12$ & $97.53 \pm 6.22$ & $<0.001$ \\
\hline SF-12 Physical & $31.61 \pm 6.15$ & $49.39 \pm 6.37$ & $<0.001$ \\
\hline SF-12 Mental & $44.82 \pm 13.18$ & $48.96 \pm 8.65$ & 0.109 \\
\hline
\end{tabular}

VAS: Visual Analog Pain Scale; ASES: Functional scale of the American Shoulder and Elbow Surgeons Standardized Shoulder Assessment Form; SF-12: Quality of life scale of the Short Form 12 Health Survey.

\section{DISCUSSION}

Arthropathy of the rotator cuff affects approximately $4 \%$ of patients with rotator cuff tears. ${ }^{13}$ The clinical manifestations of this disease are variable, and patient symptoms may be minimal with satisfactory function or range up to pseudoparalysis. ${ }^{1}$ The treatment of rotator cuff arthropathy represents a challenge to orthopedists, but reverse arthroplasty is a viable solution that can improve QOL. ${ }^{8}$

In a systematic review of the indications for reverse arthroplasty of the shoulder, Smith et al.$^{14}$ found that painful pseudoparalysis is the main reason to perform surgery. Analyzes of QOL in indicating surgery are not cited in this or other studies. ${ }^{8,14,15}$ We believe that QOL should be evaluated before and after arthroplasty, and should be part of the clinical reasoning at the time surgery is recommended. Many patients with this condition are elderly, with comorbid conditions and limitations inherent to age. ${ }^{16}$

Our results demonstrate that patients with a diagnosis of rotator cuff arthropathy and indication for reverse arthroplasty show significant impact on the physical component of QOL according to the SF-12, when compared to controls adjusted for sex and age. Sick individuals tend to have poorer outcomes on the mental component of this scale. Several studies have demonstrated the impact of osteoarthritis of the knee, ${ }^{3-6}$ the hip, ${ }^{3,5,6}$ and the hand ${ }^{6,7}$ in QOL, comparing sick individuals with healthy controls. However, these studies do not evaluate the involvement of the glenohumeral joint, whether by primary osteoarthrosis or arthropathy of the rotator cuff. The predominant impact on the physical component of QOL has been observed by other authors. ${ }^{5,6}$ Our study also stressed that the arthropathy of the rotator cuff significantly affects shoulder pain and function when these are analyzed by the VAS and ASES scale. The other studies comparing patients with osteoarthritis in other joints with healthy controls do not assess these outcomes. ${ }^{3-7,17}$ Castricini et al., ${ }^{8}$ in a study on the use of reverse arthroplasty of the shoulder in degenerative disorders (arthropathy of the rotator cuff, irreparable rupture of the rotator cuff, and primary glenohumeral arthritis), noted that the procedure provides QOL similar to that of the healthy population. Mangano et al. ${ }^{15}$ found similar results, studying only elderly patients. In a study on the use of reverse arthroplasty in proximal fractures of the humerus, Lopiz et al. ${ }^{9}$ also observed final QOL outcomes comparable to the unaffected population. However, these articles do not detail the preoperative QOL values, like the other case series evaluated. ${ }^{18-22}$ As of this writing, this present study is the first to compare QOL, function, and pain in patients with a diagnosis of rotator cuff arthropathy and an unaffected population. The groups, although they were only paired for sex and age, showed a similar distribution for most of the analyzed variables, reinforcing the validity of the inclusion criteria. It should be emphasized that the cases consumed significantly more medications than the controls, which increases the risk of side effects and drug interactions. Furthermore, the groups showed no difference in relation to BMI. Excess weight can be a confounding factor in the analysis, since obesity negatively affects QOL. ${ }^{23}$ Some authors of studies that evaluated QOL in patients with osteoarthritis of the legs did not mention this variable, ${ }^{4,5}$ while others found that the arthritis group had a higher BMI. ${ }^{6}$ Moreover, the tool we used to assess QOL, the SF-12, is self-applied, validated, and its results are comparable to the SF-36. ${ }^{10}$

This study has limitations. The sample consisted of patients with surgical indication for reverse arthroplasty for rotator cuff arthroplasty, representing only the symptomatic cases of this disease that did not improve after conservative treatment. Patients with rotator cuff arthropathy may present few symptoms and satisfactory shoulder function. ${ }^{1}$ The absence of a group of oligosymptomatic patients with rotator cuff arthropathy is the main limitation of our study. Although the sample was small, it was sufficient to prove our hypothesis, given the significant difference we found. Furthermore, the cross-sectional design did not allow us to evaluate temporal variations in the outcomes and we did not analyze pre- and postoperative pain.

\section{CONCLUSION}

Patients with rotator cuff arthropathy who were recommended for reverse arthroplasty have poorer results for the physical component of the SF-12 when compared to controls. They also had poorer functional outcomes as measured by the ASES scale and more pain as measured by the VAS.

AUTHORS' CONTRIBUTIONS: Each author made significant individual contributions to this manuscript. AAFN (0000-0001-5097-9542)* and EMT (0000$0002-2394-3808)^{*}$ contributed to the concept or design of the study and revised the article. EAM (0000-0003-1956-6445)* and JHA (0000-0002-2566-3471) * conducted the data analysis and bibliography review, and drafted the article. MECG (0000-0002-0214-9576)* and GPO $(0000-0001-5179-2907)^{\star}$ collected the data and conducted the startistical analysis. ${ }^{*} \mathrm{ORCID}$ (Open Researcher and Contributor ID).

\section{REFERENCES}

1. Visotsky JL, Basamania C, Seebauer L, Rockwood CA, Jensen KL. Cuff tea arthropathy: pathogenesis, classification, and algorithm for treatment. J Bone Joint Surg Am. 2004;86(Suppl 2):35-40

2. Nové-Josserand L, Walch G, Adeleine P, Courpron P. Effect of age on the natural history of the shoulder: a clinical and radiological study in the elderly. Rev Chir Orthop Reparatrice Appar Mot. 2005;91(6):508-14.

3. Salaffi F, Carotti M, Stancati A, Grassi W. Health-related quality of life in older adults with symptomatic hip and knee osteoarthritis: a comparison with matched healthy controls. Aging Clin Exp Res. 2005;17(4):255-63.

4. Ferreira AH, Godoy PBG, Oliveira NRC, Diniz RAS, Diniz REAS, Padovan
$\mathrm{R}$ da $\mathrm{C}$, et al. Investigação da ansiedade, depressão e qualidade de vida em pacientes portadores de osteoartrite no joelho: um estudo comparativo. Rev Bras Reumatol. 2015;55(5):434-8.

5. van der Waal JM, Terwee CB, van der Windt DAWM, Bouter LM, Dekker J. The impact of non-traumatic hip and knee disorders on health-related quality of life as measured with the SF-36 or SF-12. A systematic review. Qual Life Res. 2005;14(4):1141-55.

6. Lourenço S, Lucas R, Araújo F, Bogas M, Santos RA, Barros H. Osteoarthritis medical labelling and health-related quality of life in the general population. Health Qual Life Outcomes. 2014;12:146. 
7. Slatkowsky-Christensen B, Mowinckel P, Loge JH, Kvien TK. Health-related quality of life in women with symptomatic hand osteoarthritis: a comparison with rheumatoid arthritis patients, healthy controls, and normative data. Arthritis Rheum. 2007;57(8):1404-9.

8. Castricini R, Gasparini G, Di Luggo F, De Benedetto M, De Gori M, Galasso O Health-related quality of life and functionality after reverse shoulder arthroplasty. J Shoulder Elbow Surg. 2013;22(12):1639-49.

9. Lopiz Y, García-Coiradas J, Serrano-Mateo L, García-Fernández C, Marco F. Reverse shoulder arthroplasty for acute proximal humeral fractures in the geriatric patient: results, health-related quality of life and complication rates. Int Orthop. 2016;40(4):771-81.

10. Ware J Jr, Kosinski M, Keller SD. A 12-Item Short-Form Health Survey: construction of scales and preliminary tests of reliability and validity. Med Care. 1996;34(3):220-33.

11. Richards RR, An KN, Bigliani LU, Friedman RJ, Gartsman GM, Gristina AG, et al. A standardized method for the assessment of shoulder function. J Shoulder Elbow Surg. 1994;3(6):347-52.

12. Clement ND, MacDonald D, Simpson AHRW. The minimal clinically important difference in the Oxford knee score and Short Form 12 score after total knee arthroplasty. Knee Surg Sports Traumatol Arthrosc. 2014;22(8):1933-9.

13. Neer CS 2nd, Craig EV, Fukuda H. Cuff-tear arthropathy. J Bone Joint Surg Am. 1983;65(9):1232-44

14. Smith CD, Guyver $P$, Bunker TD. Indications for reverse shoulder replacement: a systematic review. J Bone Joint Surg Br. 2012;94(5):577-83.

15. Mangano T, Cerruti P, Repetto I, Felli L, Ivaldo N, Giovale M. Reverse shoulder arthroplasty in older patients: is it worth it? A subjective functional outcome and quality of life survey. Aging Clin Exp Res. 2016;28(5):925-33.
16. Germain CM, Vasquez E, Batsis JA, McQuoid DR. Sex, race and age differences in muscle strength and limitations in community dwelling older adults: Data from the Health and Retirement Survey (HRS). Arch Gerontol Geriatr. 2016;65:98-103.

17. Cook C, Pietrobon R, Hegedus E. Osteoarthritis and the impact on quality of life health indicators. Rheumatol Int. 2007;27(4):315-21.

18. Amaral MV, Faria JL, Siqueira G, Cohen M, Brandão B, Moraes R, et al. Artroplastia reversa do ombro no tratamento da artropatia do manguito rotador. Rev Bras Ortop. 2014;49(3):279-85.

19. Fávaro RC, Abdulahad M, Filho SM, Valério R, Superti MJ. Artropatia de manguito: o que esperar do resultado funcional da artroplastia reversa? Rev Bras Ortop. 2015;50(5):523-9.

20. Young SW, Zhu M, Walker CG, Poon PC. Comparison of functional outcomes of reverse shoulder arthroplasty with those of hemiarthroplasty in the treatment of cuff-tear arthropathy: a matched-pair analysis. J Bone Joint Surg Am. 2013;95(10):910-5.

21. Al-Hadithy N, Domos P, Sewell MD, Pandit R. Reverse shoulder arthroplasty in 41 patients with cuff tear arthropathy with a mean follow-up period of 5 years. J Shoulder Elbow Surg. 2014;23(11):1662-8.

22. Wiater JM, Moravek JE Jr, Budge MD, Koueiter DM, Marcantonio D, Wiater BP. Clinical and radiographic results of cementless reverse total shoulder arthroplasty: a comparative study with 2 to 5 years of follow-up. J Shoulder Elbow Surg. 2014;23(8):1208-14.

23. Batsis JA, Zbehlik AJ, Barre LK, Bynum JPW, Pidgeon D, Bartels SJ. Impact of obesity on disability, function, and physical activity: data from the Osteoarthritis Initiative. Scand J Rheumatol. 2015;44(6):495-502. 